\title{
Drivers of Sustainable Performance in European Energy Sector
}

\author{
Monika Wieczorek-Kosmala ${ }^{1, * \mathbb{D}}$, Dorota Marquardt ${ }^{2}$ and Jarosław Kurpanik $^{2}$ \\ 1 Faculty of Finance, University of Economics in Katowice, 40-287 Katowice, Poland \\ 2 Faculty of Informatics and Communication, University of Economics in Katowice, 40-287 Katowice, Poland; \\ dorota.marquardt@ue.katowice.pl (D.M.); jarosław.kurpanik@ue.katowice.pl (J.K.) \\ * Correspondence: m.wieczorek-kosmala@ue.katowice.pl
}

Citation: Wieczorek-Kosmala, M.; Marquardt, D.; Kurpanik, J. Drivers of Sustainable Performance in European Energy Sector. Energies 2021, 14, 7055. https://doi.org/10.3390/en14217055

Academic Editors:

Oleksandr Melnychenko and Dalia Štreimikienè

Received: 1 October 2021

Accepted: 25 October 2021

Published: 28 October 2021

Publisher's Note: MDPI stays neutral with regard to jurisdictional claims in published maps and institutional affiliations.

Copyright: (c) 2021 by the authors. Licensee MDPI, Basel, Switzerland. This article is an open access article distributed under the terms and conditions of the Creative Commons Attribution (CC BY) license (https:// creativecommons.org/licenses/by/ $4.0 /)$.

\begin{abstract}
The main purpose of this study is to identify the drivers of sustainable performance in firms that operate in the energy sector. Under the assumption of bidirectional impacts, we empirically tested the trade-offs between sustainable and financial performance, in light of neoclassical theory, the natural-resources-based view, and instrumental stakeholder theory. We hypothesize that, in the energy sector, sustainable performance is positively associated with firms' financial performance and that sustainability reporting is an important driver of sustainable performance. We add primarily by considering the relevance of sustainability-policy-oriented factors and revising the role of sustainability reporting within. We provide empirical evidence based on a large panel of firm-year observations within the 2013-2020 time span, for firms that operate in the energy sector and are located in Europe. We have found strong support for the positive link between sustainable performance (proxied with ESG score) and returns, which conforms to the assumptions of the naturalresources-based view. However, we have also found some evidence that more sustainable firms face greater costs input, which is considered in neoclassical theory. We have also confirmed no relevance of the slack-resources-based view. Finally, we found sustainability reporting to be the most influential among the set of sustainability-policy-oriented factors. This evidence demonstrates that stakeholders pressure on firms' transparency could be an important driver of sustainable performance in the energy sector.
\end{abstract}

Keywords: sustainable performance; firm's performance; sustainability reporting; energy sector

\section{Introduction}

Currently, we facilitate an increased discussion over the themes around the idea and implementation of sustainable development, both on the firm (micro) level, as well as on the policy (macro) level. Our better understanding of the drivers of firms' sustainable performance, as well as the development of the related measures and monitoring schemes, seem essential on the route to the successful implementation of the United Nations' Sustainable Development Goals (UN 2030). In the academic debate, we observe a multiplicity of works that address these issues in their link to the corporate social responsibility considerations. The perspectives are very diverse in their orientation, including the concerns on how to proxy sustainable performance, or the motivation behind and effects of sustainable performance on a firm's reputation, strategic position, and financial results [1-3]. Our work, however, is designed to add to the latter aspect, namely, the interplay between the sustainable and financial performance of a firm.

The main aim of our study is to identify the drivers of sustainable performance in firms that operate in the energy sector. Guided by prior literature, we consider the factors that could explain the link between sustainable and financial performance, in light of neoclassical theory, the natural-resources-based view, and instrumental stakeholder theory. In the empirical dimension, we apply regression to explain firms' sustainable performance and the financial-performance-related variables. We expand considerations of the resources-based view, by addressing various types of firms' slack resources. We also add 
to the existing debate by revising the importance of a set of sustainability-policy-oriented variables, with particular attention given to the effects of sustainability reporting.

The major contribution of our work is that we examine the energy sector in isolation. Prior empirical works commonly revise a wider range of sectors (e.g., [4]). However, we control for the energy sector selectively, to obtain a relative homogeneity of the sample, given the effects of their performance from an environmental perspective (and, in particular, their position within ESIs—environmentally sensitive industries). Further, we focus on European firms only, as the regional differences seem to be influential on the understanding and pursuance of the idea of sustainable performance. For instance, the European Union enhances and initiates strategies within environmental considerations, which could create a unique environment for the scope and nature of the sustainable behavior of firms located in Europe. Our work also contributes by providing evidence on a large number of firm-year observations, in a relatively long time horizon (2013-2020).

Another important contribution of our work is that we consider the potential effects of the stakeholders' pressure, by addressing the set of variables that are commonly used to explain a firm's sustainability policy. In particular, we focus on the effects of sustainable reporting, to answer a question on the role of sustainability reporting in enhancing a firm's sustainable performance. In other words, we address the problem of transparency and the role of a sustainable report as a tool of positive pressure. In this aspect, our study adds to the very current debate on the overall role of sustainability reporting and the related regulatory framework $[5,6]$, as well as to the recent findings targeted at the energy sector (e.g., [7]).

The remainder of this paper is organized as follows. In the second section, we develop two research hypotheses, based on the literature review within the interplay of sustainable and financial performance and stakeholders' pressure on firms' transparency. In the third section, we explain the empirical design of our study, in this, the composition of the sample, variables selection, and model. In Section 4, we present and discuss the results. Section 5 concludes.

\section{Literature Review and Hypothesis Development}

\subsection{The Interplay between Sustainable and Financial Performance}

In the rich body of the extant literature, the problems of firms' sustainable performance and the related corporate social responsibility are revised from a variety of angles. In this work, however, we remain focused on one stream in this debate, namely, the interplay between the sustainable and financial performance of a firm, with a moderating role of stakeholders' pressure. The sustainable performance of a firm is manifested by its approach to environmental, social, and governance (hereafter referred to as ESG) concerns. The abbreviation "ESG" is commonly used in the related literature [8]. The environmental component refers to the firm's perspective on the management of resources, in this, energy efficiency and water disposal, circular economy, preservation of natural environment, and maintenance of biodiversity, as well as climate change and greenhouse gas emissions are included. The social component covers a wide range of a firm's activities targeted at its employees and customers and approach to human-rights-related issues, on the route to building and maintaining social relationships. Finally, the governance component refers to a firm's corporate governance mechanisms that enhance the appropriate implementation of policies that address environmental and social concerns.

The ESG considerations are deeply rooted in stakeholder theory [9], which assumes the satisfaction of interests of heterogenous groups of entities bounded with a company in the network of interdependencies. In line with stakeholder theory, companies are regarded as the entities that function within society and, thus, are expected to perform in a sustainable manner on their route to shareholder (owner) satisfaction.

However, the stakeholder theory stimulates an ongoing debate on the trade-off effects between a firm's sustainable performance (SP) and financial performance (FP) [10]. The extant literature provides rich but ambiguous evidence within. As pointed by [11] or [12] in 
their meta-analyses, since the 1970s, scholars have published a considerable body of works that provide inconclusive or contradictory findings, which is often driven by different methodical approaches. In this debate, there is evidence on the impacts of sustainable performance on financial performance $(\mathrm{SP} \rightarrow \mathrm{FP})$. There are also works that revise the reversed nexus - the impacts of financial performance on sustainable performance (FP $\rightarrow \mathrm{SP})$.

The impacts of sustainable performance on financial performance (SP $\rightarrow \mathrm{FP})$ are commonly studied through the lenses of neoclassical theory (negative link), the naturalresources-based view (positive link), or instrumental stakeholder theory (positive link). The negative link between sustainable and financial performance is driven by the view that sustainable performance is costly. It requires new investments or changes in the management approaches, often amplified by compliance costs. Consistently with neoclassical theory, some industries (in the energy sector) face high compliance costs, as they operate under law requirements that pursue sustainable behavior [4,13].

On the other hand, there is a view that sustainable performance enhances financial performance. In light of the natural-resources-based view (developed by [14]), sustainable performance fosters the development of rare and inimitable resources and capabilities. These, in turn, enhance a firm's competitive advantage and better financial performance $[11,15,16]$. For instance, the investments in more environmentally friendly technologies may stimulate innovations, the implementation of social policies may increase employees skills and involvement, and better governance is a positive signal to investors.

In light of instrumental stakeholder theory, sustainable performance attracts stakeholders, by meeting their expectations (e.g., [17-19]). A firm that meets the claims of key stakeholders gains competitive advantage by increased reputation and stronger long-term relationships $[11,20]$. However, the reputation context is vague, as it could be the sole motivation to be involved in sustainable actions. This threat is highlighted by the window dressing hypothesis and raises skepticism over the effectiveness of CSR practices [21].

There is a growing body of literature that considers a non-linear impact of sustainable performance on financial performance. For instance, [22-24] provide evidence on Ushaped relationships. Although investment in sustainable performance initially diminishes profits, over time, it brings benefits that counterbalance the initial costs. Firm-specific characteristics remain influential on the turning point in this U-shaped relationship [25].

In the explanation of the effects of financial performance on sustainable performance $(\mathrm{FP} \rightarrow \mathrm{SP})$, the extant literature commonly refers to the slack resources hypothesis. Slack resources are defined as the resources that a company holds in excess of its needs. In their buffering function, slack resources support adaptive strategies if facing internal or external pressures for change [26]. In this regard, slack resources are supportive in implementing sustainability strategies and the related managerial practices, to enhance sustainable performance [27-30]. The moderating role of slack resources is explained by the observation that better financial performance is associated with higher slack holdings [31]. In this respect, better financial performance could be regarded as an important driver of sustainable performance.

The energy sector is listed among the environmentally sensitive industries (ESI). Thus, in the energy sector, we expect to observe a positive link between sustainable and financial performance, consistently with the foundations of the natural-resources-based theory and instrumental stakeholder theory. In light of the extant literature that provides strong arguments for the consideration of a bidirectional nexus between sustainable and financial performance, we formulate our fist hypothesis as follows:

Hypothesis 1 (H1). In the energy sector, sustainable performance is positively associated with firms' financial performance.

\subsection{The Relevance of Transparency and Reporting}

The link between sustainable and financial performance could be moderated by the stakeholders' pressure on a firm's transparency. In the existing literature, there is rich 
evidence that stakeholders' pressure enhances a firm's accountability and transparency in the pursuit of sustainable performance (e.g., [32-37]). Moreover, the existence of the mechanisms that increase a firm's transparency is influential on a firm's sustainable behavior. To enhance transparency and satisfy the information needs of the stakeholders, firms report on their sustainable performance [38,39]. However, there is evidence that firms tend to disclose only the positive aspects of their sustainable performance and avoid reporting harmful practices [40-44]. Thus, there is a temptation to use sustainability reports as a tool of impression management, which reveals one facet of window dressing behavior. To prevent such practices and ascertain more objective and transparent information, the mandatory regulations have been implemented on the European Commission level (the Directive 2014/95/EU on non-financial information [45,46]), as essential in enhancing a firm's sustainable performance within, in fostering the Sustainable Development Goals (UN 2030 [47]). On one hand, the implementation of a mandatory reporting regime increases the costs of compliance, which conforms to the natural-resources-based hypothesis. On the other hand, however, the mandatory reporting regime is expected to exert an impact on firms' behavior and practices and improve their ESG activities [48-54]. Thus, in our study, we hypothesize that, in the energy sector, firms that release the reports on their sustainable performance are distinguished by better ESG activities:

Hypothesis 2 (H2). In the energy sector, sustainability reporting positively impacts sustainable performance.

\section{Research Design and Methods}

\subsection{Sample Selection Scheme}

For the purposes of this study, we use the data available in Refinitiv Eikon Datastream. The database offers i.a. accounting-based figures for the listed firms that perform worldwide. We requested for data in the 2013-2020 time span, for the listed firms that perform in European countries in the energy sector. To select the companies that operate in the energy sector, we controlled for both the Refinitiv Eikon sector classification (the TRBC Economic Sector Name), as well as the NAICS international industry name and NAICS industry group name (which is provided by Refinitiv Eikon as well). In addition, we have manually controlled for the correctness of this classification, by revising the convergence of industry classification for each firm in our sample.

Under the above specified request terms, we have initially obtained 2665 firm-year observations. However, after filtering out the records with missing entries, we have finally obtained a panel of 2545 firm-year observations. The composition of our sample in cross country and time dimension is presented in Table 1.

\subsection{Variable Measurement and Data}

The set of variables that we implement in this study is presented in Table 2. In light of our hypotheses, our main variable of interest is a firm's sustainable performance, with control variables that refer to a firm's financial performance and a firm's sustainability policy.

To proxy the sustainable performance, we use the ESG score (ESG_SC), which is provided by Refinitiv Eikon Datastream. In the extant literature, various measures of a firm's sustainable performance have been previously used, ranging from self-developed and disclosure-based indices (e.g., [55]), through the use of the selected variables as proxies of environmental performance (e.g., greenhouse gas emissions in [4]) to the sustainability ratings developed by various agencies (e.g., AR, Vigeo, Ethical Investment Research Service, ASSET4 by Thomson Reuters, or Down Jones Sustainability Indexes, among others, see [56]). The variety of existing methodical approaches has resulted in a plethora of studies on the topic, but of limited possibilities to compare between the findings, due to the significant methodical differences between the computation of the scores $[12,57,58]$. However, there is a growing number of recent works that apply the ESG scores from Refinitiv Eikon (formerly 
Thomson Reuters) to proxy firms' sustainable performance. For instance, the Refinitiv Eikon has been recently applied by [59-62], and [7] for the energy sector.

Table 1. Sample composition—cross country and time dimension.

\begin{tabular}{|c|c|c|c|c|c|c|c|c|c|}
\hline \multirow{2}{*}{ Country } & \multicolumn{8}{|c|}{ Year } & \multirow{2}{*}{ In Total } \\
\hline & 2013 & 2014 & 2015 & 2016 & 2017 & 2018 & 2019 & 2020 * & \\
\hline Austria & 4 & 4 & 4 & 4 & 4 & 5 & 4 & 4 & 33 \\
\hline Belgium & 5 & 5 & 5 & 5 & 5 & 5 & 5 & 5 & 40 \\
\hline Bosnia and Herc. & 10 & 10 & 11 & 12 & 12 & 12 & 12 & 12 & 91 \\
\hline Bulgaria & 5 & 5 & 5 & 5 & 5 & 5 & 6 & 6 & 42 \\
\hline Croatia & 2 & 3 & 3 & 3 & 3 & 3 & 3 & 3 & 23 \\
\hline Cyprus & 4 & 4 & 3 & 5 & 5 & 5 & 6 & 4 & 36 \\
\hline Czech Rep. & 1 & 1 & 1 & 1 & 1 & 1 & 1 & 1 & 8 \\
\hline Denmark & 3 & 3 & 3 & 4 & 4 & 3 & 4 & 5 & 29 \\
\hline Finland & 3 & 3 & 3 & 3 & 3 & 3 & 3 & 3 & 24 \\
\hline France & 14 & 15 & 16 & 16 & 18 & 19 & 18 & 18 & 134 \\
\hline Germany & 19 & 19 & 20 & 19 & 18 & 18 & 17 & 18 & 148 \\
\hline Greece & 11 & 11 & 11 & 12 & 11 & 14 & 14 & 13 & 97 \\
\hline Hungary & 3 & 4 & 4 & 3 & 3 & 4 & 4 & 4 & 29 \\
\hline Ireland & 4 & 4 & 4 & 4 & 5 & 6 & 6 & 5 & 38 \\
\hline Italy & 13 & 14 & 14 & 14 & 15 & 16 & 15 & 16 & 117 \\
\hline Lithuania & 2 & 2 & 2 & 2 & 2 & 3 & 3 & 3 & 19 \\
\hline Luxembourg & 4 & 4 & 5 & 5 & 5 & 4 & 4 & 4 & 35 \\
\hline Macedonia & 1 & 1 & 1 & 2 & 2 & 2 & 2 & 2 & 13 \\
\hline Malta & 1 & 1 & 1 & 1 & 1 & 1 & 1 & 1 & 8 \\
\hline Monaco & 2 & 2 & 2 & 2 & 2 & 2 & 2 & 2 & 16 \\
\hline Montenegro & 2 & 2 & 2 & 2 & 2 & 2 & 2 & 2 & 16 \\
\hline Netherlands & 9 & 9 & 10 & 9 & 10 & 10 & 10 & 9 & 76 \\
\hline Norway & 33 & 32 & 33 & 37 & 44 & 46 & 46 & 47 & 318 \\
\hline Poland & 16 & 17 & 20 & 21 & 20 & 21 & 21 & 20 & 156 \\
\hline Portugal & 3 & 3 & 3 & 3 & 3 & 3 & 3 & 3 & 24 \\
\hline Romania & 16 & 17 & 15 & 17 & 17 & 17 & 17 & 17 & 133 \\
\hline Serbia & 2 & 2 & 3 & 3 & 3 & 3 & 3 & 3 & 22 \\
\hline Slovenia & 1 & 1 & 0 & 0 & 0 & 1 & 1 & 1 & 5 \\
\hline Spain & 6 & 7 & 7 & 8 & 7 & 10 & 11 & 11 & 67 \\
\hline Sweden & 10 & 15 & 18 & 18 & 17 & 17 & 18 & 18 & 131 \\
\hline Switzerland & 5 & 5 & 5 & 5 & 5 & 5 & 4 & 4 & 38 \\
\hline Ukraine & 13 & 12 & 13 & 13 & 12 & 10 & 6 & 2 & 81 \\
\hline United Kingdom & 54 & 58 & 59 & 61 & 57 & 63 & 65 & 65 & 482 \\
\hline In total & 283 & 297 & 308 & 321 & 323 & 341 & 339 & 333 & 2545 \\
\hline
\end{tabular}

Notes: * data requested as on end of July 2021, thus the number of observations for 2020 offer data for newly rated firms, with the missing data for some firms rated in 2019. Due to the pandemic, the reporting period for many firms has been exchanged, and the database is continuously supplemented, as the information is published by particular companies.

An important advantage of the ESG score from Refinitiv Eikon is that it is computed in a transparent and objective manner, given the data reported by firms in a public domain The score weighs both the positives, as well as the controversies; thus, it could be regarded as not biased with window dressing and impression management. The ESG score from Refinitiv Eikon measures a firm's sustainable performance across ten major themes. In the environmental component, it rates resource use, emissions, and innovation. In the social component, it rates workforce, human rights, community, and product responsibility. In the governance component, it rates management, shareholders, and CSR strategy. The components are differently weighted and cover in total more than 450 various firm-level indicators, both on a dichotomous level, as well as on a parametric level, where applicable. In the final ESG score, the environmental component prevails, followed by the social component and governance component. Ultimately, the Refinitiv Eikon Datastream provides the ESG score ranging from 0 to 100, and scores higher than 75 are interpreted as indicating excellent ESG performance and a high degree of a firm's transparency in reporting their 
ESG performance in the public domain. In our further empirical procedure, we additionally implement the ESG-score-based dummy variable (ESG_dum), to demarcate between the energy firms (and the related firm-year observations) with the ESG score (1) and without the ESG score (0).

Table 2. Variables and their definitions.

\begin{tabular}{cc}
\hline Variable & Definition \\
ESG_SC & $\begin{array}{r}\text { Sustainable performance } \\
\text { ESG_dum }\end{array}$ \\
ESG score, as provided by Refinitiv Eikon \\
1 if a firm has ESG score, 0 otherwise
\end{tabular}

Further, we implement a set of measures that reflect a firm's financial performance. The accounting-based figures needed to compute these variables have also been obtained from Refinitiv Eikon Datastream. To capture the context of a firm's efficiency, we implement return on assets (ROA), consistently with prior works that revise the interplay between firms' sustainable and financial performance (e.g., $[4,27,59,63-65])$. In addition, we implement a set of measures that are less common, but are informative in the context of a firm's performance, if we consider the cost-related perspective. More specifically, we implement the operating profit margin (OPM), computed as operating profit to sales revenues, and the productivity of assets (PA), computed as sales revenues to total assets. High OPM indicates that a firm faces a relatively lower burden of operating costs and, thus, is favored with greater profitability on a sales-oriented level. High PA indicates that a firm is able to use its resources in a more productive way.

We also implement a range of measures that are informative in the context of holdings of slack resources. Following the set of indicators of organizational slack resources proposed by Bourgeois [26] and further development of measures of slack by Bourgeois and Singh [66], we distinguish between three types of slack resources: available, recoverable, and potential. Available slack is defined as cash hold by the company in excess of its needs and, thus, is commonly proxied with cash ratio (CA-cash relative to assets), consistently with [67] or [68]. However, following [69,70], we additionally employ a current ratio of liquidity (CR) as an alternative hallmark of available slack holdings. The recoverable slack is defined as the resources that have already been committed (absorbed), and it requires time to recover these resources. In this respect, consistently with Bourgeois and Singh's [66] suggestion, we measure recoverable slack with sales, general, and administrative expenses to sales (SGA/S). Lower levels of this ratio indicate a greater recoverable slack holding, as less sales revenues is consumed by a firm's costs, thus increasing the firm's profitability. 
The potential slack is defined as resources that could be obtained by the company in the future. Thus, a common measure of potential slack is a firm's financial leverage, proxied in our study as debt to assets (DA). Higher levels of DA indicate lower potential slack, as firms with high debt burden are regarded as more financially constrained and, thus, have limited capabilities to obtain external funding [31,71]. Financial leverage and current ratio of liquidity have also been considered as control variables in prior works on the link between sustainable and financial performance (e.g., $[4,25,72])$. Consistently with these works, we also control for a firm's size, proxied by natural logarithm of a firm's assets (SIZE). This is justified, given the pressure of mandatory sustainability reporting on large and listed firms in particular.

Finally, we implement a set of dummy variables that could be informative in the context of a firm's overall policy within the sustainable performance. In light of our second hypothesis, our major variable of interest is a dummy of whether a firm issues a report on its sustainable performance or not (REPORT). However, we additionally implement the set of variables that could be influential on a firm's pursuance of ESG actions. According to [73], a firm's incentives to meet stakeholders' needs could be manifested by voluntary participation in UN Global Compact. Thus, following [74], we implement a dummy of whether a firm is a signatory of United Nations Global Compact (UNGC). With similar reasoning behind it, we additionally control for the implementation of a firm's CSR policy, by considering whether a firm has a CSR committee or team (CSR) or holds ESG-related certificates (CERT). All these dummies are obtainable from Refinitiv Eikon Datastream.

\subsection{Methods}

We test our first hypothesis in a two-stadial procedure. At the first stage of our investigations, we implement the U Mann-Whitney test to compare between the ESG score holders and non-holders, guided by the ESG_dum variable (more specifically, to compare firm-year observations with and without ESG score). At the univariate analysis level, we seek for the differences in a firm's financial performance. At the second stage of our investigations, we revise more in depth the group of firm-year observations with the ESG rating (ESG_dum $=1$ ). For this group, we perform weighted least square (WLS) regression for ESG_SC as the dependent variable and the range of explanatory variables that refer to a firm's financial performance (to further develop Hypothesis 1). In this respect, our empirical model is as follows:

$\mathrm{ESG}_{\mathrm{SC}}=\beta_{0}+\beta_{1} \mathrm{ROA}+\beta_{2} \mathrm{OPM}+\beta_{3} \mathrm{PA}+\beta_{4} \mathrm{SGA} / \mathrm{S}+\beta_{5} \mathrm{CA}+\beta_{6} \mathrm{CR}+\beta_{7} \mathrm{D} / \mathrm{A}+\beta_{8} \mathrm{SIZE}+\varepsilon$

Further, to address the relevance of sustainability-policy-oriented factors, we perform univariate analysis (U Mann-Whitney test), to compare the medians of ESG_SC between the groups of firm-year observations (Hypothesis 2). Our groups are defined on a dichotomous level, depending on whether they fulfill the criteria defined in the set of policy-oriented variables: REPORT, UNGC, CSR, and CERT.

\section{Results and Discussion}

\subsection{Sustainable and Financial Performance (Hypothesis 1)}

In our sample of European firms that operate in the energy sector, there was on av. 23\% of firms rated with a Refinitiv Eikon ESG score, given the 2013-2020 time span of analysis. However, as it can be seen in Figure 1, this percentage is constantly growing, ranging from $20.85 \%$ in 2013 to $29.50 \%$ in 2019 . A considerable increase is visible between 2016 and 2017-2018, which seems to be driven by the implementation of the EU directive on non-financial reporting that mandated the largest companies (so called PIES-public interest entities) to provide extended information on their sustainable performance. 


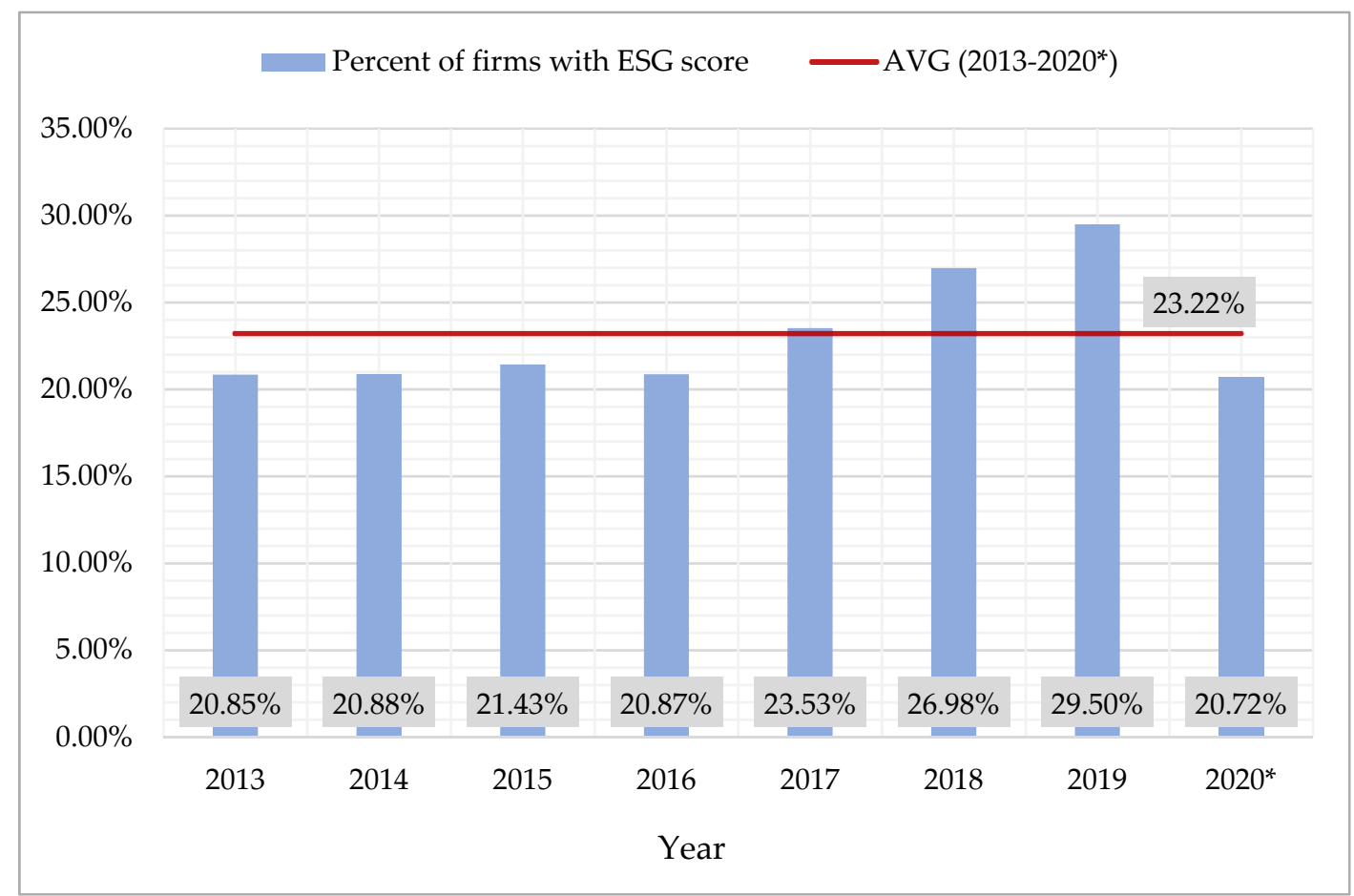

Figure 1. Sample composition-percentage of European energy sector firms that are rated with an ESG score. Notes: * data requested as of end of July 2021, thus the number of observations for 2020 is illustrative, as it gives the mid-term effects (see explanation in notes to Table 1).

At the first stage of our investigations, we have compared the financial performance of firm-year observations that are rated with a Refinitiv Eikon ESG score (ESG_dum $=1$ ) with those that are not rated $\left(E S G \_d u m=0\right)$. The results are reported in Table 3, on a non-parametric (U Mann-Whitney test) level, as our dataset is not normally distributed (normality tests are presented in Appendix A Table A1). We observe statistically significant differences between all variables, except from CA (cash to assets) and CR (current ratio of liquidity). In the group of variables that reflect the effectiveness of operating performance (ROA, OPM, and PA), the mean ranks of the U Mann-Whitney test clearly indicate that the firm-year observations rated with an ESG score are distinguished by a higher return on assets, have a greater operating profit margin, and have a better productivity of assets. Similarly, the firm-year observations rated with an ESG score are distinguished by a lower burden of operating costs (SGA/S). These observations indicate that firms that perform in a sustainable manner and are subject to ESG scoring are distinguished by better financial performance.

The U Mann-Whitney test has also clearly indicated that the available slack (proxied with CA and CR) is not associated with sustainable performance. Further, we observe that potential slack is also not supportive in the pursuance of sustainable performance, as DA for firm-year observations with an ESG score was higher than in the group of firm-year observations without an ESG score (which is confirmed by higher ranks of the U Mann-Whitney test for DA, reported in Table 3). In other words, ESG-rated firm-year observations are distinguished by higher level of debts, relative to assets, which signals possible financial constraints and restricts their capabilities to obtain additional funding, as potential financial slack. We also find at a statistically significant level that firm-year observations with an ESG score are larger (SIZE), if we consider the size of their sales revenues.

On the second stage of our investigations, we have revised more in depth the group of firm-year observations with the ESG_SC, to confirm whether similar evidence stands if we consider the height of the ESG score. Overall, as it can be seen in Figure 2, in the examined 
sample of European energy companies, the ESG_SC on average slightly increases over time.

Table 3. Comparison between the groups (ESG_dum $=0$ vs. ESG_dum $=1$ ) -univariate analysis.

\begin{tabular}{cccccc}
\hline Variable & $\begin{array}{c}\text { Mean Ranks } \\
\text { No ESG_SC }\end{array}$ & $\begin{array}{c}\text { Mean Ranks } \\
\text { ESG_SC }\end{array}$ & U Mann-Whitney & Sig. & \\
\hline ROA & 1208.8 & 1485.2 & $452,022.000$ & 0.000 & $* * *$ \\
OPM & 1176.95 & 1567.50 & $397,447.000$ & 0.000 & $* * *$ \\
PA & 1218.61 & 1452.81 & $471,137.000$ & 0.000 & $* * *$ \\
SGA/S & 1342.38 & 912.17 & $361,231.500$ & 0.000 & $* * *$ \\
CA & 1261.89 & 1309.72 & $555,703.500$ & 0.166 & \\
CR & 1272.88 & 1237.02 & $556,142.500$ & 0.296 & \\
DA & 1234.08 & 1401.69 & $501,348.500$ & 0.000 & $* * *$ \\
SIZE & 1031.76 & 2070.59 & $106,032.000$ & 0.000 & $* * *$ \\
\hline
\end{tabular}

Notes: "no ESG_SC" denotes a group of firm-year observations ( $n=1954)$ that are not rated with a Refinitiv Eikon ESG score (ESG_dum $=0)$, "ESG_SC" denotes a group of firm-year observations $(n=591)$ rated with a Refinitiv Eikon ESG score $\left(E S G \_d u m=1\right)$. Statistically significant at: ${ }^{* * *} \alpha=0.001,{ }^{* *} \alpha=0.01,{ }^{*} \alpha=0.05$.

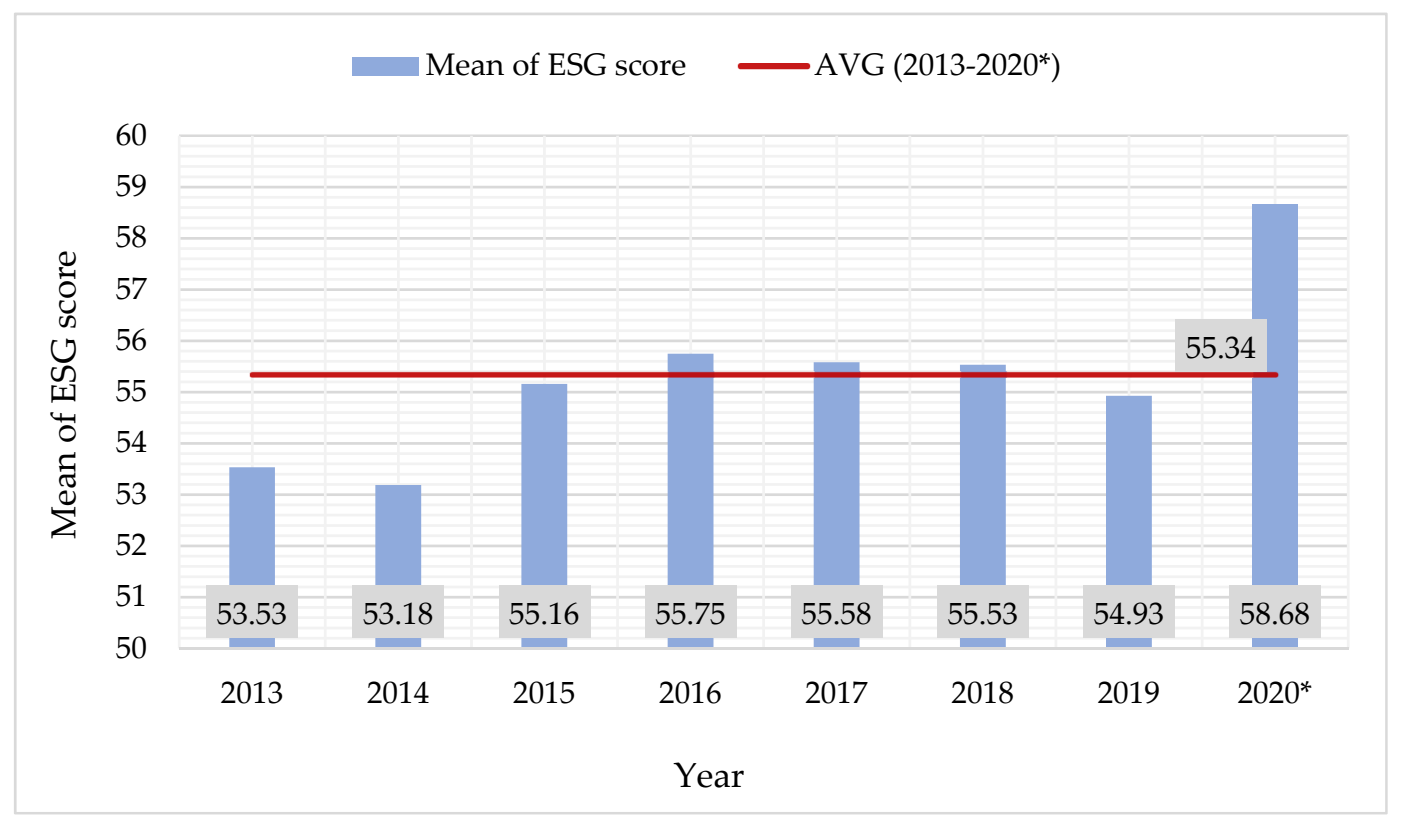

Figure 2. Average values of ESG_SC for sampled companies in the European energy sector. Notes: * data requested as of end of July 2021, thus the number of observations for 2020 is illustrative, as it gives the mid-term effects (see explanation in notes to Table 1).

Prior to running regression analysis, we have revised the correlations between ESG_SC as our main dependent variable and the remaining explanatory variables, which are presented in Table 4. We observe that ESG_SC is positively and statistically significantly correlated with leverage and potential slack holdings (DA), as well as profit-cost-oriented variables (ROA, PA, and SGA/S). We also observe a negative correlation with available financial slack variables (CR and CA). The strongest correlation is observed between ESG_SC and SIZE.

In Table 5, we present regression results. At the first stage of regression analysis, we have confirmed heteroskedasticity of our data, by applying the Breusch-Pagan test $(p<0.05)$. Thus, to handle the problem of heteroskedasticity, we applied weighted least square (WLS) regression, following [75]. We first ran the ordinary least square (OLS) regression, and then, we used the absolutes of the residuals to create weights for the WLS regression. For the diagnostic of multicollinearity, we controlled for VIF, which was not a concern in our case (VIF below 10). We have also winsorized the data prior to regression at 
1 percentile, to avoid an impact of the possible outliers due to biased entries. Given the $\mathrm{R}^{2}$, our model explains $80.1 \%$ of the cases, which we find a very satisfactory level of model fit.

Table 4. Correlation matrix.

\begin{tabular}{cccccccccc}
\hline & ESG_SC & ROA & OPM & PA & CR & CA & DA & SGA/S & SIZE \\
\hline ESG_SC & 1 & $0.088^{*}$ & 0.042 & $0.121^{* *}$ & $-0.267^{* * *}$ & $-0.095^{*}$ & $0.234^{* * *}$ & $0.081^{*}$ & $0.646^{* * *}$ \\
ROA & $0.088^{*}$ & 1 & $0.255^{* * *}$ & $0.165^{* * *}$ & 0.037 & $0.013^{* *}$ & $-0.276^{* * *}$ & $-0.024^{* *}$ & $0.118^{* *}$ \\
OPM & $0.042^{* * *}$ & $0.255^{* * *}$ & 1 & $-0.134^{* *}$ & -0.013 & $-0.225^{* * *}$ & $0.006^{*}$ & $0.248^{* * *}$ & $0.218^{* * *}$ \\
PA & $0.121^{* *}$ & $0.165^{* * *}$ & $-0.134^{* *}$ & 1 & $-0.112^{* *}$ & $0.101^{*}$ & $0.104^{*}$ & $-0.131^{* *}$ & 0.063 \\
CR & $-0.267^{* * *}$ & $0.037^{* *}$ & -0.013 & $-0.112^{* *}$ & 1 & $0.213^{* * *}$ & $-0.428^{* * *}$ & $-0.028^{*}$ & $-0.244^{* * *}$ \\
CA & $-0.095^{*}$ & 0.013 & $-0.225^{* * *}$ & $0.101^{*}$ & $0.213^{* * *}$ & 1 & $-0.086^{*}$ & 0.000 & $-0.263^{* * *}$ \\
DA & $0.234^{* * *}$ & $-0.276^{* * *}$ & $0.006^{* *}$ & $0.104^{*}$ & $-0.428^{* * *}$ & $-0.086^{*}$ & 1 & -0.053 & $0.131^{* *}$ \\
SGA/S & $0.081^{*}$ & -0.024 & $0.248^{* * *}$ & $-0.131^{* *}$ & -0.028 & $0.000^{* *}$ & -0.053 & 1 & $0.123^{* *}$ \\
SIZE & $0.646^{* * *}$ & $0.118^{* *}$ & $0.218^{* * *}$ & 0.063 & $-0.244^{* * *}$ & $-0.263^{* * *}$ & $0.131^{* *}$ & $0.123^{* *}$ & 1 \\
\hline
\end{tabular}

Notes: Table presents Pearson's correlation coefficients. Statistically significant at: ${ }^{* * *} \alpha=0.001,{ }^{* *} \alpha=0.01,{ }^{*} \alpha=0.05 . n=591$.

Table 5. Regression results for ESG_SC as dependent variable.

\begin{tabular}{ccccccc}
\hline Parameters & B & St. Err & St. Beta & T & Sig. & VIF \\
\hline Intercept & $-113.512^{* * * *}$ & 6.559 & & -17.307 & 0.000 & \\
ROA & $14.002^{* *}$ & 5.656 & 0.052 & 2.476 & 0.014 & 1.276 \\
OPM & $-2.332^{*}$ & 1.298 & -0.046 & -1.797 & 0.073 & 1.897 \\
PA & $-9.157^{* * * *}$ & 0.808 & -0.262 & -11.337 & 0.000 & 1.555 \\
SGA $/ S$ & $2.323^{* * * *}$ & 0.441 & 0.101 & 5.270 & 0.000 & 1.073 \\
CA & 8.729 & 7.051 & 0.026 & 1.238 & 0.216 & 1.289 \\
CR & $-0.201^{*}$ & 0.112 & -0.073 & -1.805 & 0.072 & 4.816 \\
DA & $19.075^{* * * *}$ & 3.179 & 0.199 & 6.001 & 0.000 & 3.193 \\
SIZE & $7.586^{* * *}$ & 0.270 & 0.815 & 28.147 & 0.000 & 2.440
\end{tabular}

Notes: $R^{2}=0.803$, Adj. $R^{2}=0.801, F=292.590^{* * *}$. Statistically significant at: ${ }^{* * * *} \alpha=0.001,{ }^{* * *} \alpha=0.01,{ }^{* *} \alpha=0.05$, ${ }^{*} \alpha=0.01$.

The regression results confirm that more profitable firms perform in a more sustainable manner, as the regression slope for ESG_SC and ROA is positive (+14.002) and statistically significant at $5 \%$. This supports our first hypothesis and conforms to the natural-resourcesbased view, consistent with findings provided, e.g., by [72]. However, we also find that firms with higher ESG_SC tend to have a lower operating profit margin, as the regression slope for OPM and ESG_SC is negative (-2.332), significant at 5\%. The firms with higher ESG_SC also tend to have lower productivity of assets (PA), as the regression slope is negative (-9.157) and strongly statistically significant at $0.1 \%$. We also observe that firms with higher ESG_SC face a higher burden of operating costs (sales, general, and administrative expenses), as the regression slope for recoverable slack (SGA/S) is positive (+2.323) and strongly statistically significant at $0.1 \%$. These observations for OPM, PA, and SGA/S give some support to neoclassical theory, as they indicate greater operating cost loading in more sustainable firms in the energy sector. This also suggests that recoverable slack holdings are not supportive in the pursuance of ESG policies in the energy sector.

The regression results provide no support for slack resource view as regards available and potential slack resources. First of all, we observe that available slack holdings (CA) are statistically insignificant. The alternative measure of available slack resources (CR) is statistically significant at $5 \%$, with the negative regression slope, but is of relatively weak association $(-0.201)$. However, we observe strong association in the case of potential financial slack (DA), with a positive regression slope of +19.075 . In light of this evidence, the slack resource hypothesis finds no support, as more sustainable firms are more financially constrained and, thus, are not distinguished by potential financial slack. Once again, regression provides strong support for the interplay between sustainable performance and a firm's size $(+7.586$, significant at $0.1 \%)$, which is consistent with the prior observations of [72] or [8]. 
Overall, the regression results are partially consistent with what we observed in our initial univariate analysis, by comparing firm-year observations with and without an ESG score. First, for the profit-cost-oriented variables of financial performance, we observed that firms rated with an ESG score achieved better results than those that were not rated. However, if we consider the group of ESG score holders only (which was subject to WLS regression analysis), we observe that a higher ESG score is associated with better ROA, but these firms have a lower operating profit margin, lower productivity of assets, and face a higher burden of costs (SGA/S). In particular, the latter observation for SGA/S indicates limited space for applying recoverable slack resources in increasing sustainable performance.

If we consider available and potential slack, however, the regression results are fully consistent with what we observe in univariate analysis. Overall, firms of better sustainable performance tend to be more financially constrained (as confirmed by higher DA). In addition, these firms do not hold available financial slack (CA) to support their sustainable performance, which is not conforming to the slack resources view.

\subsection{The Relevance of Sustainability Policy (Hypothesis 2)}

To address the relevance of sustainability-policy-related variables, we have applied the U Mann-Whitney test, to compare between the groups, defined as the firm-year observations with (group 1) and without (group 2) the given policy item of our interest. In other words, our binary variables (REPORT, UNGC, CSR, and CERT) were used to test the differences in the ESG-rated firm-year observations. The results of the analysis are provided in Table 6. For all sustainability-oriented variables, we observe statistically significant differences between the groups of our firm-year observations. We observe that firm-year observations with sustainability reports (REPORT) that are signatories of the United Nations Global Compact (UNGC), have implemented CSR policy (CSR) or hold the sustainability-related certification (CERT) are distinguished by visibly higher ESG scores, in comparison to firm-year observations without these attributes.

Table 6. The results of U Mann-Whitney test for sustainability policy variables.

\begin{tabular}{|c|c|c|c|c|c|c|c|c|}
\hline \multirow{2}{*}{ Variable } & \multicolumn{2}{|c|}{ NO } & \multicolumn{2}{|c|}{ YES } & \multirow{2}{*}{ U Mann-Whitney } & \multirow{2}{*}{ W-Wilcoxon } & \multirow{2}{*}{$\mathbf{Z}$} & \multirow{2}{*}{ Sig. } \\
\hline & $n$ & Ranks & $n$ & Ranks & & & & \\
\hline REPORT & 64 & 68.09 & 527 & 323.68 & 2278.000 & 4358.000 & -11.308 & 0.000 \\
\hline UNGC & 295 & 189.41 & 296 & 402.23 & $12,216.000$ & $55,876.000$ & -15.150 & 0.000 \\
\hline CSR & 173 & 165.89 & 418 & 349.85 & $13,648.000$ & $28,699.000$ & -11.917 & 0.000 \\
\hline CERT & 161 & 189.88 & 430 & 335.73 & $17,530.000$ & $30,571.000$ & -9.245 & 0.000 \\
\hline
\end{tabular}

Further, we have analyzed the medians of ESG scores for our firm-year observations for each group and within a given attribute of our interest. The results are illustrated in Figure 3. In light of our second hypothesis, our major interest is in the effect of sustainable reporting. The differences in medians presented in Figure 3 clearly indicate that among the sustainability-policy-oriented variables considered in our study, the sustainability report (REPORT) is the most influential on the ESG scores assigned to the firms. In other words, in the case of the group of firms that issue the sustainability reports, as compared to these that do not, the differences in the height of ESG_SC are the strongest. It suggests that a firm's transparency and disclosures in sustainable reports remains strongly influential on their ESG ratings. 


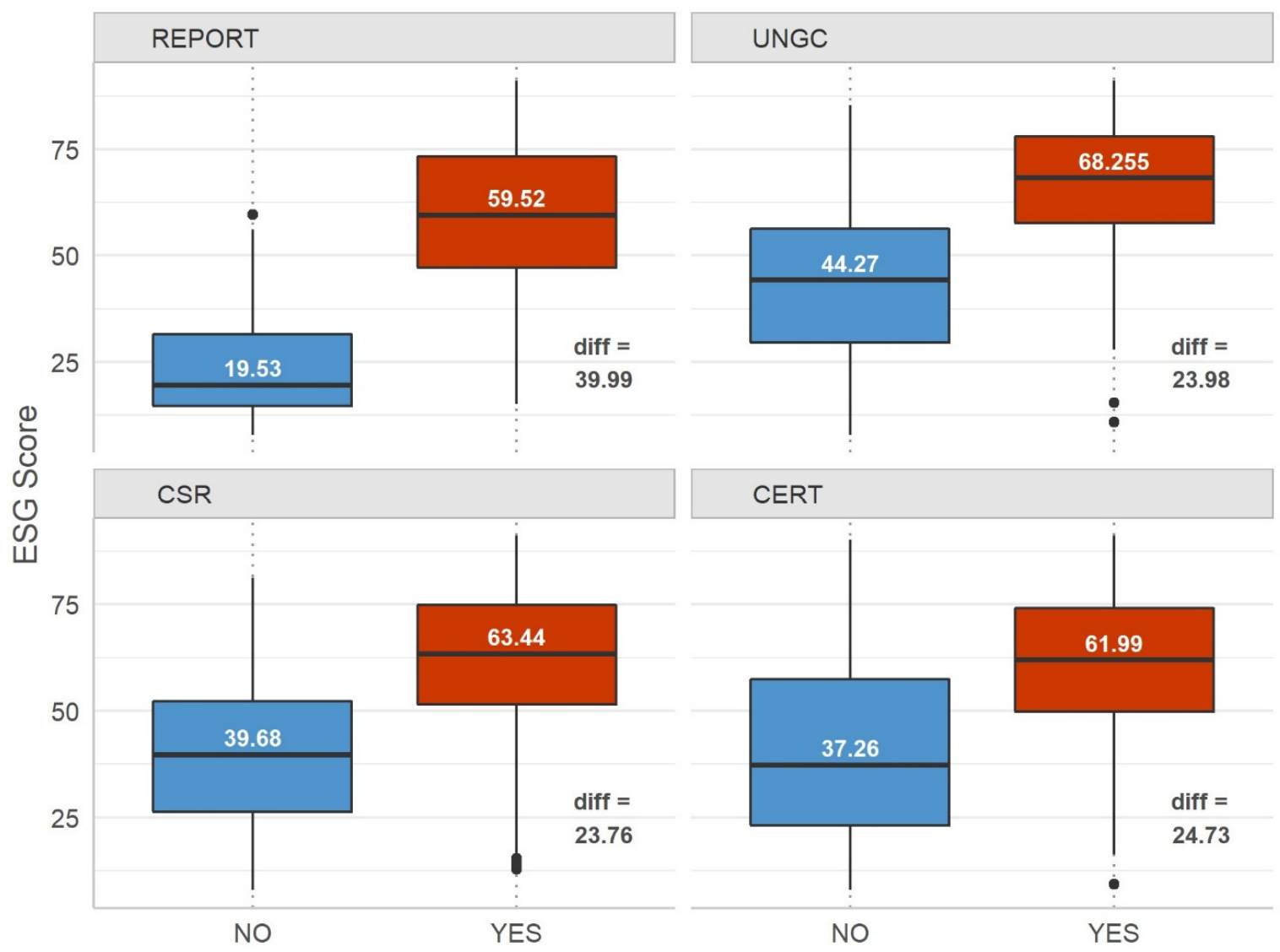

Figure 3. Differences in medians of ESG_SC between the firm-year observations with sustainability policy attributes (REPORT, UNGC, CSR, CERT).

\section{Conclusions}

The purpose of our study was to revise the drivers of sustainable performance of firms that operate in the European energy sector, by considering the trade-offs with financial performance. This aspect of our research was conceptually rooted in the considerations of neoclassical theory, the natural-resources-based view, and instrumental stakeholder theory. In our study, we have additionally revised the impacts of sustainability policy that reflect the response to stakeholders' pressure.

The first hypothesis tested in this study was that sustainable performance is positively associated with a firm's financial performance. However, our evidence is vague, depending on which aspect of a firm's financial performance we consider and on the level of empirical analysis. For a firm's profitability (proxied in our study with return on assets), we find strong evidence on the positive link with sustainable performance. While comparing the firm-year observations with and without an ESG score on a dichotomous level, we observed higher profitability in the group of firm-year observations with an ESG score. While revising more in depth the group of firm-year observations with an ESG score, regression results have confirmed strong associations between higher ESG score and ROA. This evidence is consistent with the assumptions of the natural-resources-based view and instrumental stakeholder theory.

Our evidence is mixed, however, if we consider the recoverable slack resources. First of all, on a univariate level (comparison of firm-year observations with and without an ESG rating), we find strong evidence that firms with an ESG score have a greater operating profit margin, better productivity of assets, and are less loaded with an operating costs burden. The latter aspect supports the importance of recoverable slack resources in the pursuance of sustainable performance. However, if we consider the firm-year observations with the ESG score, the regression results have provided strong support for neoclassical 
theory and the greater cost burden in firms that perform in a more sustainable manner. Thus, our first hypothesis finds partial support for better financial performance proxied by profit-cost-oriented variables (OPM, PA, and SGA/S).

Finally, we have found sound evidence on the irrelevance of the slack-resources-based view if the available and potential financial slack resources are considered. For available financial slack, we have found statistically insignificant associations on a univariate level, which was further confirmed in the regression analysis for firm-year observations with an ESG rating. However, we have found strong evidence for the positive link between sustainable performance and financial leverage (proxied as debt to assets). Firms that are rated with an ESG score are distinguished by a higher level of financial leverage. Similarly, regression results indicate that the height of an ESG score is associated with financial leverage. Our evidence demonstrates that sustainable performance is linked to higher financial constraints and a lower level of potential slack resources. Thus, we do not find convincing arguments to support the slack resources view for potential financial slack in the energy sector.

Given this empirical evidence, our first hypothesis found partial support. In the energy sector, more sustainable firms are more profitable, but face higher costs and, thus, limited potential slack resources. However, these firms are also more financially constrained and, thus, are limited in their potential financial slack holdings. In light of this inconclusive evidence, we ask for further studies that will revise the ESG score holders in more depth, to examine the sustainable and financial performance trade-offs with the mediating role of capital structure decisions.

Our second hypothesis was that sustainability reporting positively impacts sustainable performance. We have considered sustainability reporting among other variables that could reflect a firm's sustainability policy. We have found strong support for this hypothesis, as sustainability reporting was the most influential on the height of the ESG score, compared to the remaining sustainability-policy-oriented drivers (UNGC signatory, CSR policy implementation, or certification). This evidence could be regarded as a signal of the potential window dressing practices. However, we proxied sustainable behavior with an objective score (ESG score by Refinitiv Eikon), which also considers a negative loading of unsustainable practices. From our evidence, it clearly stands that sustainability reports play an important role in enhancing a firm's sustainable performance. Thus, transparency and the mandatory reporting requirements emerge as relevant policy tools in fostering the Sustainable Development Goals.

There are several limitations of our study. A first important limitation of our work is that it does not account for the impact of country specifics. Our evidence is driven primarily by the practices of energy firms that operate on core European Union markets, as these countries were visibly prevalent in our sample if we consider their loading on the firm-year observations level. On one hand, this strengthens our evidence, as our sample covers countries where the pursuance of firms' sustainable behavior has a longer history and is supported by stronger regulatory mechanisms. On the other hand, it justifies the need to design further inquiries that will address in more depth the situation in the emerging European economies, as isolated country settings. Finally, on the country level, further inquiries should be placed to detect the possible differences between the countries and to revise the rationale (or lack of) behind the prevalence of studies that assume country-level homogeneity. Similar consideration applies to the energy sub-sectors, as the differences between the firms that produce energy or are involved in the related utilities sector could be potentially important. Thus, we recommend that further works (on smaller samples or more case-study-oriented ones) should address the country-level and sector-specific differences in the understanding of the foundations of sustainable performance, then, the stage of its implementation, and finally, the specifics of the energy sector's performance in domestic market contexts.

Our study has highlighted the importance of sustainability reports in achieving higher ESG ratings by firms. Thus, we believe that further studies could address in greater 
detail the potential power of the implementation of mandatory regimes for sustainability reporting. There again, there are differences in the pursuance of regulatory frameworks both on the country level, as well as in the time dimension. Thus, we believe that more detailed studies on the situation in energy companies, on the given country level, could add to the debate on the drivers of sustainable performance. In particular, the qualitative studies of greater granularity could be informative in this respect, with a focus on particular activities implemented by energy companies in the pursuance of their sustainable goals.

Author Contributions: Conceptualization, M.W.-K. and D.M.; methodology, M.W.-K. and J.K., software, J.K., validation, J.K.; formal analysis, M.W.-K. and J.K.; resources, D.M.; data curation, J.K.; writing—original draft preparation, M.W.-K. and D.M.; writing—review and editing, D.M.; visualization, J.K.; supervision, M.W.-K.; project administration, M.W.-K.; funding acquisition, M.W.-K. All authors have read and agreed to the published version of the manuscript.

Funding: This research was funded by the University of Economics in Katowice, grant "Beyond Barriers" number 02/BB/01/2021. The APC was funded by the University of Economics in Katowice.

Institutional Review Board Statement: Not applicable.

Informed Consent Statement: Not applicable.

Data Availability Statement: The data presented in this work have been produced by the authors. The entry accounting-based figures were obtained from the Refinitiv Eikon Datastream, and the access was provided by Refinitiv Poland. Data accessed 28 July 2021.

Acknowledgments: We gratefully acknowledge Refinitiv Poland for providing us with access to their database Refinitiv Eikon Datastream. We are also grateful to the anonymous Referees of this paper for their insightful comments.

Conflicts of Interest: The authors declare no conflict of interest.

\section{Appendix A}

Table A1. Tests of normality distribution.

\begin{tabular}{ccccccc}
\hline \multirow{2}{*}{ Variables } & \multicolumn{3}{c}{ Kołmogorov-Smirnov } & \multicolumn{3}{c}{ Shapiro-Wilk } \\
\cline { 2 - 7 } & Statistic & df & Sig. & Statistic & df & Sig. \\
\hline ESG_SC & 0.051 & 582 & 0.001 & 0.973 & 582 & 0.000 \\
ROA & 0.175 & 582 & 0.000 & 0.644 & 582 & 0.000 \\
OPM & 0.280 & 582 & 0.000 & 0.476 & 582 & 0.000 \\
PA & 0.160 & 582 & 0.000 & 0.782 & 582 & 0.000 \\
CA & 0.116 & 582 & 0.000 & 0.830 & 582 & 0.000 \\
CR & 0.275 & 582 & 0.000 & 0.371 & 582 & 0.000 \\
SGA/S & 0.070 & 582 & 0.000 & 0.941 & 582 & 0.000 \\
DA & 0.424 & 582 & 0.000 & 0.134 & 582 & 0.000 \\
SIZE & 0.037 & 582 & 0.062 & 0.987 & 582 & 0.000 \\
\hline
\end{tabular}

Table A2. Descriptive statistics for the examined financial-performance-related variables.

\begin{tabular}{|c|c|c|c|c|c|c|c|}
\hline Variable & Min & Max & Median & Mean & St. Dev. & Skewness & Kurtosis \\
\hline \multicolumn{8}{|c|}{ observations without ESG score $(\mathrm{n}=1954)$} \\
\hline ROA & -1.66 & 0.40 & 0.0002 & -0.0858 & 0.28406 & -3.355 & 14.089 \\
\hline OPM & -211.34 & 3.38 & 0.0291 & -5.8043 & 28.11552 & -6.197 & 39.665 \\
\hline PA & 0.00 & 6.24 & 0.2668 & 0.6625 & 1.11831 & 3.260 & 11.337 \\
\hline SGA/S & 0.01 & 132.81 & 0.2191 & 4.1271 & 18.27645 & 6.059 & 37.539 \\
\hline CA & 0.00 & 0.76 & 0.0735 & 0.1346 & 0.15708 & 2.000 & 4.199 \\
\hline $\mathrm{CR}$ & 0.08 & 27.74 & 1.3783 & 2.7960 & 4.31997 & 3.881 & 17.156 \\
\hline DA & 0.02 & 2.23 & 0.5339 & 0.5518 & 0.37401 & 1.482 & 4.589 \\
\hline SIZE & 2.17 & 24.51 & 17.3922 & 16.9654 & 3.02444 & -0.670 & 0.422 \\
\hline \multicolumn{8}{|c|}{ observations with ESG score $(n=591)$} \\
\hline ROA & -1.62 & 0.40 & 0.0203 & -0.0003 & 0.12882 & -5.048 & 54.699 \\
\hline OMP & -7.11 & 3.38 & 0.1012 & 0.1761 & 0.64403 & -2.012 & 45.559 \\
\hline PA & 0.00 & 4.13 & 0.4139 & 0.6083 & 0.60868 & 2.242 & 6.878 \\
\hline SGA/S & 0.01 & 27.39 & 0.0924 & 0.3413 & 1.75008 & 11.590 & 150.762 \\
\hline CA & 0.00 & 0.76 & 0.0891 & 0.1068 & 0.08698 & 2.262 & 9.308 \\
\hline CR & 0.12 & 27.74 & 1.3703 & 1.7979 & 2.26363 & 8.359 & 88.056 \\
\hline DA & 0.02 & 2.23 & 0.6117 & 0.5931 & 0.21395 & 0.607 & 6.076 \\
\hline SIZE & 14.27 & 26.58 & 21.2572 & 21.3922 & 1.92879 & 0.234 & 0.465 \\
\hline
\end{tabular}




\section{References}

1. Vishwanathan, P.; van Oosterhout, H.; Heugens, P.P.M.A.R.; Duran, P.; Van Essen, M. Strategic CSR: A Concept Building Meta-Analysis. J. Manag. Stud. 2019, 57, 314-350. [CrossRef]

2. Mio, C.; Panfilo, S.; Blundo, B. Sustainable development goals and the strategic role of business: A systematic literature review. Bus. Strat. Environ. 2020, 29, 3220-3245. [CrossRef]

3. Pope, S.; Waeraas, A. CSR-Washing is Rare: A Conceptual Framework, Literature Review, and Critique. J. Bus. Eth. 2015, 137, 173-193. [CrossRef]

4. Tzouvanas, P.; Kizys, R.; Chatziantoniou, I.; Sagitova, R. Environmental disclosure and idiosyncratic risk in the European manufacturing sector. Energy Econ. 2020, 87, 104715. [CrossRef]

5. Mio, C.; Fasan, M.; Marcon, C.; Panfilo, S. The predictive ability of legitimacy and agency theory after the implementation of the EU directive on non-financial information. Corp. Soc. Responsib. Environ. Manag. 2020, 27, 2465-2476. [CrossRef]

6. Cordazzo, M.; Bini, L.; Marzo, G. Does the EU Directive on non-financial information influence the value relevance of ESG disclosure? Italian evidence. Bus. Strat. Environ. 2020, 29, 3470-3483. [CrossRef]

7. Karaman, A.S.; Orazalin, N.; Uyar, A.; Shahbaz, M. CSR achievement, reporting, and assurance in the energy sector: Does economic development matter? Energy Policy 2020, 149, 112007. [CrossRef]

8. Fatemi, A.; Glaum, M.; Kaiser, S. ESG performance and firm value: The moderating role of disclosure. Glob. Financ. J. 2018, 38, 45-64. [CrossRef]

9. Freeman, R.E. Strategic Management: A Stakeholder Approach; Pitman: Boston, MA, USA, 1984.

10. Weber, O. The financial sector's impact on sustainable development. J. Sustain. Financ. Invest. 2014, 4, 1-8. [CrossRef]

11. Endrikat, J.; Guenther, E.; Hoppe, H. Making sense of conflicting empirical findings: A meta-analytic review of the relationship between corporate environmental and financial performance. Eur. Manag. J. 2014, 32, 735-751. [CrossRef]

12. Friede, G.; Busch, T.; Bassen, A. ESG and financial performance: Aggregated evidence from more than 2000 empirical studies. J. Sustain. Finance Invest. 2015, 5, 210-233. [CrossRef]

13. Wagner, M.; van Phu, N.; Wehrmeyer, W. The relationship between the environmental and economic performance of firms: An empirical analysis of the European paper industry. Corp. Soc. Responsib. Environ. Manag. 2002, 9, 133-146. [CrossRef]

14. Hart, S.L. A Natural-Resource-Based View of the Firm. Acad. Manag. Rev. 1995, 20, 986. [CrossRef]

15. Chan, R.Y.K. Does the Natural-Resource-Based View of the Firm Apply in an Emerging Economy? A Survey of Foreign Invested Enterprises in China. J. Manag. Stud. 2005, 42, 625-672. [CrossRef]

16. Hart, S.L.; Dowell, G. Invited Editorial: A Natural-Resource-Based View of the Firm. J. Manag. 2010, 37, 1464-1479. [CrossRef]

17. Donaldson, T.; Preston, L.E. The Stakeholder Theory of the Corporation: Concepts, Evidence, and Implications. Acad. Manag. Rev. 1995, 20, 65. [CrossRef]

18. Jones, T.M. Instrumental Stakeholder Theory: A Synthesis of Ethics and Economics. Acad. Manag. Rev. 1995, 20, 404. [CrossRef]

19. Buysse, K.; Verbeke, A. Proactive environmental strategies: A stakeholder management perspective. Strat. Manag. J. 2002, 24, 453-470. [CrossRef]

20. Surroca, J.; Tribó, J.A.; Waddock, S. Corporate responsibility and financial performance: The role of intangible resources. Strat. Manag. J. 2009, 31, 463-490. [CrossRef]

21. Connors, S.; Anderson-Macdonald, S.; Thomson, M. Overcoming the 'Window Dressing' Effect: Mitigating the Negative Effects of Inherent Skepticism towards Corporate Social Responsibility. J. Bus. Ethics 2015, 145, 599-621. [CrossRef]

22. Nollet, J.; Filis, G.; Mitrokostas, E. Corporate social responsibility and financial performance: A non-linear and disaggregated approach. Econ. Model. 2016, 52, 400-407. [CrossRef]

23. Trumpp, C.; Guenther, T.W. Too Little or too much? Exploring U-shaped Relationships between Corporate Environmental Performance and Corporate Financial Performance. Bus. Strat. Environ. 2015, 26, 49-68. [CrossRef]

24. Lewandowski, S. Corporate Carbon and Financial Performance: The Role of Emission Reductions. Bus. Strat. Environ. 2017, 26, 1196-1211. [CrossRef]

25. Broadstock, D.C.; Managi, S.; Matousek, R.; Tzeremes, N.G. Does doing "good" always translate into doing "well"? An eco-efficiency perspective. Bus. Strat. Environ. 2019, 28, 1199-1217. [CrossRef]

26. Bourgeois, L.J. On the Measurement of Organizational Slack. Acad. Manag. Rev. 1981, 6, 29. [CrossRef]

27. Waddock, S.A.; Graves, S.B. The corporate social performance-financial performance link. Strateg. Manag. J. 1997, 18, 303-319. [CrossRef]

28. Bansal, P. Evolving sustainably: A longitudinal study of corporate sustainable development. Strat. Manag. J. 2004, 26, 197-218. [CrossRef]

29. Russo, M.V.; Fouts, P.A. A resource-based perspective on corporate environmental performance and profitability. Acad. Manag. J. 1997, 40, 534-559. [CrossRef]

30. Kock, C.J.; Santaló, J.; Diestre, L. Corporate Governance and the Environment: What Type of Governance Creates Greener Companies? J. Manag. Stud. 2011, 49, 492-514. [CrossRef]

31. Daniel, F.; Lohrke, F.T.; Fornaciari, C.J.; Turner, R. Slack resources and firm performance: A meta-analysis. J. Bus. Res. 2004, 57, 565-574. [CrossRef]

32. Helfaya, A.; Moussa, T. Do Board's Corporate Social Responsibility Strategy and Orientation Influence Environmental Sustainability Disclosure? UK Evidence. Bus. Strat. Environ. 2017, 26, 1061-1077. [CrossRef] 
33. Hovardas, T.; Poirazidis, K. Environmental Policy Beliefs of Stakeholders in Protected Area Management. Environ. Manag. 2007, 39, 515-525. [CrossRef]

34. Zarzycka, E.; Krasodomska, J. Non-financial key performance indicators: What determines the differences in the quality and quantity of the disclosures? J. Appl. Account. Res. 2021. ahead-of-print. [CrossRef]

35. Aureli, S.; Gigli, S.; Medei, R.; Supino, E. The value relevance of environmental, social, and governance disclosure: Evidence from Dow Jones Sustainability World Index listed companies. Corp. Soc. Responsib. Environ. Manag. 2019, 27, 43-52. [CrossRef]

36. Kaur, A.; Lodhia, S. Stakeholder engagement in sustainability accounting and reporting. Account. Audit. Account. J. 2018, 31, 338-368. [CrossRef]

37. Hahn, T.; Pinkse, J.; Preuss, L.; Figge, F. Tensions in Corporate Sustainability: Towards an Integrative Framework. J. Bus. Ethics 2014, 127, 297-316. [CrossRef]

38. Fasan, M.; Mio, C. Fostering Stakeholder Engagement: The Role of Materiality Disclosure in Integrated Reporting. Bus. Strat. Environ. 2016, 26, 288-305. [CrossRef]

39. Gallego-Álvarez, I.; Ortas, E. Corporate environmental sustainability reporting in the context of national cultures: A quantile regression approach. Int. Bus. Rev. 2017, 26, 337-353. [CrossRef]

40. Ballou, B.; Chen, P.-C.; Grenier, J.H.; Heitger, D.L. Corporate social responsibility assurance and reporting quality: Evidence from restatements. J. Account. Public Policy 2018, 37, 167-188. [CrossRef]

41. Birkey, R.N.; Michelon, G.; Patten, D.M.; Sankara, J. Does assurance on CSR reporting enhance environmental reputation? An examination in the U.S. context. Account. Forum 2016, 40, 143-152. [CrossRef]

42. Peters, G.F.; Romi, A.M. The Association between Sustainability Governance Characteristics and the Assurance of Corporate Sustainability Reports. Audit. J. Pract. Theory 2014, 34, 163-198. [CrossRef]

43. Niskanen, J.; Nieminen, T. The objectivity of corporate environmental reporting: A study of Finnish listed firms' environ-mental disclosures. Bus. Strategy Environ. 2001, 10, 29-37. [CrossRef]

44. Talbot, D.; Boiral, O. Strategies for Climate Change and Impression Management: A Case Study Among Canada's Large Industrial Emitters. J. Bus. Ethics 2014, 132, 329-346. [CrossRef]

45. Directive 2014/95/EU of the European Parliament and of the Council of 22 October 2014. 2014. Available online: https: / / eur-lex.europa.eu/legal-content/EN/TXT/PDF/?uri=CELEX:32014L0095\&from=EN (accessed on 1 October 2021).

46. EC. Guidelines on Non-Financial Reporting (Methodology for Reporting Non-Financial Information). 2017. Available online: https:/ / eur-lex.europa.eu/legal-content/EN/TXT/?uri=CELEX:52017XC0705(01) (accessed on 1 October 2021).

47. United Nations. Sustainable Development Goals; SDGs 2030; United Nations: New York, NY, USA, 2015.

48. Barth, M.E. Research, Standard Setting, and Global Financial Reporting. Found. Trends Account. 2006, 1, 71-165. [CrossRef]

49. Hail, L.; Leuz, C.; Wysocki, P.D. Global Accounting Convergence and the Potential Adoption of IFRS by the U.S. (Part I): Conceptual Underpinnings and Economic Analysis. Account. Horizons 2010, 24, 355-394. [CrossRef]

50. Eccles, R.G.; Krzus, M.P.; Ribot, S. Models of Best Practice in Integrated Reporting 2015. J. Appl. Corp. Finance 2015, $27,103-115$. [CrossRef]

51. De George, E.; Li, X.; Shivakumar, L. A review of the IFRS adoption literature. Rev. Account. Stud. 2016, 21, 898-1004. [CrossRef]

52. Christensen, H.B.; Floyd, E.; Liu, L.Y.; Maffett, M. The real effects of mandated information on social responsibility in financial reports: Evidence from mine-safety records. J. Account. Econ. 2017, 64, 284-304. [CrossRef]

53. Christensen, H.B.; Hail, L.; Leuz, C. Adoption of SCR and Sustainability Reporting Standards: Economic Analysis and Review, NEBER Working Papers 2019. Working Paper 26169. 2019. Available online: http:/ / www.nber.org/papers/w26169 (accessed on 15 September 2021). [CrossRef]

54. Muserra, A.L.; Papa, M.; Grimaldi, F. Sustainable Development and the European Union Policy on Non-Financial Information: An Italian Empirical Analysis. Corp. Soc. Responsib. Environ. Manag. 2019, 27, 22-31. [CrossRef]

55. Clarson, P.M.; Li, Y.; Richardson, G.D.; Vasvari, F.P. Revisiting the relationship between environmental performance and environmental disclosure: An empirical analysis. Account. Organ. Soc. 2008, 33, 303-327. [CrossRef]

56. Escrig-Olmedo, E.; Muñoz-Torres, M.J.; Fernández-Izquierdo, M.; Rivera-Lirio, J.M. Lights and shadows on sustainability rating scoring. Rev. Manag. Sci. 2013, 8, 559-574. [CrossRef]

57. Drempetic, S.; Klein, C.; Zwergel, B. The Influence of Firm Size on the ESG Score: Corporate Sustainability Ratings Under Review. J. Bus. Ethics 2019, 167, 333-360. [CrossRef]

58. Dimson, E.; Marsh, P.; Staunton, M. Divergent ESG Ratings. J. Portf. Manag. 2020, 47, 75-87. [CrossRef]

59. Demers, E.; Hendrikse, J.; Joos, P.; Lev, B. ESG did not immunize stocks during the COVID-19 crisis, but investments in intangible assets did. J. Bus. Financ. Account. 2021, 48, 433-462. [CrossRef]

60. Duque-Grisales, E.; Aguilera-Caracuel, J. Environmental, Social and Governance (ESG) Scores and Financial Performance of Multilatinas: Moderating Effects of Geographic International Diversification and Financial Slack. J. Bus. Ethics 2019, 168, 315-334. [CrossRef]

61. Jost, S.; Erben, S.; Ottenstein, P.; Zülch, H. Does corporate social responsibility impact mergers \& acquisition premia? New international evidence. Finance Res. Lett. 2021, 102237. [CrossRef]

62. Shakil, M.H. Environmental, social and governance performance and financial risk: Moderating role of ESG controversies and board gender diversity. Resour. Policy 2021, 72, 102144. [CrossRef] 
63. Horváthová, E. The impact of environmental performance on firm performance: Short-term costs and long-term benefits? Ecol. Econ. 2012, 84, 91-97. [CrossRef]

64. Buallay, A. Is sustainability reporting (ESG) associated with performance? Evidence from the European banking sector. Manag. Environ. Qual. Int. J. 2019, 30, 98-115. [CrossRef]

65. Rossi, M.; Chouaibi, J.; Chouaibi, S.; Jilani, W.; Chouaibi, Y. Does a Board Characteristic Moderate the Relationship between CSR Practices and Financial Performance? Evidence from European ESG Firms. J. Risk Financ. Manag. 2021, 14, 354. [CrossRef]

66. Bourgeois, L.J.; Singh, J.V. Organizational Slack and Political Behavior Among Top Management Teams. Acad. Manag. Proc. 1983, 1983, 43-47. [CrossRef]

67. Vanacker, T.; Collewaert, V.; Paeleman, I. The Relationship between Slack Resources and the Performance of Entrepreneurial Firms: The Role of Venture Capital and Angel Investors. J. Manag. Stud. 2013, 50, 1070-1096. [CrossRef]

68. Han, S.; Qiu, J. Corporate precautionary cash holdings. J. Corp. Financ. 2007, 13, 43-57. [CrossRef]

69. Bromiley, P. Testing a Causal Model of Corporate Risk Taking and Performance. Acad. Manag. J. 1991, 34, 37-59. [CrossRef]

70. George, G. Slack Resources and the Performance of Privately Held Firms. Acad. Manag. J. 2005, 48, 661-676. [CrossRef]

71. Wieczorek-Kosmala, M.; Błach, J. Financial Slack and Company's Risk Retention Capacity. In Multiple Perspectives in Risk and Risk Management, Proceedings of the ERRN 8th European Risk Conference, Katowice, Poland, 20-21 September 2018; Linsley, P., Shrives, P., Wieczorek-Kosmala, M., Eds.; Springer: New York, NY, USA, 2019; pp. 145-168. [CrossRef]

72. Velte, P. Does ESG performance have an impact on financial performance? Evidence from Germany. J. Glob. Responsib. 2017, 8, 169-178. [CrossRef]

73. Cetindamar, D. Corporate Social Responsibility Practices and Environmentally Responsible Behavior: The Case of The United Nations Global Compact. J. Bus. Ethics 2007, 76, 163-176. [CrossRef]

74. Baboukardos, D.; Mangena, M.; Ishola, A. Integrated thinking and sustainability reporting assurance: International evidence. Bus. Strat. Environ. 2021, 30, 1580-1597. [CrossRef]

75. Olvera Astivia, O.; Zumbo, B. Heteroskedasticity in Multiple Regression Analysis: What It Is, How to Detect It and How to Solve It with Applications in R and SPSS. Pract. Assess. Res. Eval. 2019, 24, 1. [CrossRef] 